\title{
Managing ecosystems without prior knowledge: pathological outcomes of lake liming
}

\author{
$\underline{\text { David G. Angeler }}^{1}, \underline{\text { Stina Drakare }}^{1}, \underline{\text { Richard K. Johnson }}^{1}$, Stephan Köhler $^{1}$ and Tobias Vrede $^{1}$
}

\begin{abstract}
Management actions often need to be taken in the absence of ecological information to mitigate the impact of pressing environmental problems. Managers counteracted the detrimental effects of cultural acidification on aquatic ecosystems during the industrial era using liming to salvage biodiversity and ecosystem services. However, historical contingencies, i.e., whether lakes were naturally acidic or degraded because of acidification, were largely unknown and therefore not accounted for in management. It is uncertain whether liming outcomes had a potentially detrimental effect on naturally acidic lakes. Evidence from paleolimnological reconstructions allowed us to analyze community structure in limed acidified and naturally acidic lakes, and acidified and circumneutral references. We analyzed community structure of phytoplankton, zooplankton, macroinvertebrates (littoral, sublittoral, profundal), and fish between 2000 and 2004. Naturally acidic limed lakes formed communities that were not representative of the other lake types. The occurrence of fish species relevant for ecosystem service provisioning (fisheries potential) in naturally acidic limed lakes were confounded by biogeographical factors. In addition, sustained changes in water quality were conducive to harmful algal blooms. This highlights a pathological outcome of liming lakes when their naturally acidic conditions are not accounted for. Because liming is an important socialecological system, sustained ecological change of lakes might incur undesired costs for societies in the long term.
\end{abstract}

Key Words: biodiversity; community structure; ecosystem history; fish; invertebrates; lakes; liming; management; phytoplankton; zooplankton

\section{INTRODUCTION}

Managers often need to act swiftly and without prior ecological information of ecosystems to mitigate the impact of pressing environmental problems. Anthropogenic acidification of surface waters has been a major environmental problem in northern Europe and eastern North America during the epoch of flourishing industrial activity. Acid rain impacted aquatic ecosystems by lowering $\mathrm{pH}$ and increasing aluminium concentrations beyond lethal toxic thresholds for organisms, leading to a loss of biodiversity and profound alteration of community structure and ecosystem processes (Schindler 1988). To mitigate acidification impacts, many countries implemented large-scale mitigation programs based on lime application to surface waters and catchments (Henrikson and Brodin 1995, Sandoy and Romunstad 1995). For example, in Sweden, some 5000 lakes and $9000 \mathrm{~km}$ of watercourses were limed at a yearly cost of $\sim € 1.8$ million to restore biodiversity, i.e., facilitate the recovery of threatened acid-sensitive biota, and create conditions for recreational and commercial fishing and aquaculture, i.e., protect and enhance existing fish populations (Appelberg and Svenson 2001, SEPA 2007).

Studies from Europe and North America have reported mixed results regarding biological responses to liming (Clair and Hindar 2005). In lakes, liming has often, but not always, induced improvements in fish (Appelberg and Degerman 1991), phytoplankton (Renberg and Hultberg 1992), zooplankton (Stenson and Svensson 1995) and benthic macroinvertebrates (Persson and Appelberg 2001). Equivocal biological responses to liming have been attributed to context dependent abiotic and biotic factors (Yan et al. 2003, Binks et al. 2005). These factors include fluctuations in water chemistry caused by repeated liming and reacidification events, dispersal capacities of organisms, the characteristics of their habitats, and taxon-specific time lags (Angeler and Goedkoop 2010).
Some of these effects may also be attributable to ecosystem history that can influence management outcomes (Fischer et al. 2001). For instance, results of a reciprocal zooplankton transplantation experiment indicated that changes in acid tolerance of populations during past acidification events may make zooplankton communities less sensitive to subsequent pH stress (Fischer et al. 2001). Thus, systems with historically high acidity (naturally acidic systems) may have communities that are adapted to acidic conditions. There is also evidence that ecosystem history interacts with disturbance regimes. For instance, biodiversity in grasslands, which have been exposed to severe chronic stress for centuries were at increased risk when exposed to new disturbance regimes (Van der Wurff et al. 2007). It follows that interactions between ecosystem historical factors and altered disturbance regimes may have complex but potentially severe negative effects on ecosystems.

Repeated liming of streams and lakes has been regarded as a substantial alteration of natural disturbance regimes (Bishop et al. 2001, McKie et al. 2006). There is paleolimnological evidence, which was not available when commencing large-scale liming programs, that acidification management in Sweden resulted in liming of naturally acidic and culturally acidified lakes (Norberg et al. 2008). It is unknown whether ecosystem history (naturally acidic conditions) interacts with the alteration of disturbance regimes due to liming. We hypothesize that liming of naturally acidic lakes has substantial undesired ecological impacts that offset targeted management outcomes (conservation of threatened, acid sensitive taxa [fish, crayfish, flood pearl mussel], and biodiversity at large). Using monitoring data from the Swedish Integrated Liming Effect Studies (IKEU) program, we assess community structure across trophic levels (phytoplankton, zooplankton, invertebrates, fish) and habitats (pelagic, benthic), which allows for ecosystem level inference of liming impacts. 
Liming comprises a strongly coupled social-ecological system with governmental investments amounting roughly to $€ 31$ million each year (Karlsson 2013). Important socioeconomic benefits derive from liming for instance with recreational fisheries. Alone in 2013 recreational fisheries generated expenditures of approximately $€ 5$ million and $\sim 9000 \mathrm{t}$ of harvest were landed inland (HaV 2013). Additionally, liming is important for commercial fishing and fish farming and species and biotope conservation, and it also contributes to tourism, environmental awareness, and human health, i.e., reducing levels of mercury and caesium in fish (Bengtsson and Bogelius 1995). Thus, liming plays a role for creating jobs and revenue. It follows that assessments of ecosystem level impacts are necessary to understand the ramifications for the socioeconomic components of this social-ecological system.

\section{MATERIAL AND METHODS}

\section{Data assembly}

We evaluated data of phytoplankton, zooplankton, and fish in the pelagic and macroinvertebrate communities in three benthic habitat types (littoral, sublittoral, and profundal) of selected lakes available in the Swedish liming (IKEU) and national lake monitoring databases (Fölster et al. 2014). We analyzed a five-year period between 2000 and 2004 for 12 lakes for which data across taxonomic groups were available (Table 1, Fig. 1). Six lakes were limed of which three were naturally acidic and three culturally acidified (Norberg et al. 2008). Three acidified (unlimed) and three circumneutral lakes served as references. Acidified lakes have been identified based on biogeochemical modeling criteria (Fölster et al. 2007). Almost all lakes were situated in the mixed forest ecoregion of southern Sweden. Some of their water quality variables are shown in Table 1.

Samples were collected in August (phytoplankton and zooplankton), in October (macroinvertebrates), and in July or August (fish). Analyses were based on biovolume data for phytoplankton $\left(\mathrm{mm}^{3} \mathrm{~L}^{-1}\right)$ and zooplankton $\left(\mathrm{mm}^{3} \mathrm{~m}^{-3}\right)$, and biomass data for sublittoral and profundal macroinvertebrates ( $\mathrm{g}$ $\mathrm{m}^{-2}$ ), and fish ( $\mathrm{g}$ catch per unit effort [CPUE]) as well as semiquantitative abundance data (individuals per CPUE) for littoral macroinvertebrates. Although the use of different units limits quantitative comparisons between organism groups, it allowed for assessing liming outcomes from a qualitative perspective, e.g., approximation of community structure and trophic relationships in limed lakes to target circumneutral conditions. The taxonomic groups have been identified using standard methods described in the monitoring program (https:// www.slu.se/en/departments/aquatic-sciences-assessment/).

\section{Sampling procedures}

For water quality analyses we used August values of surface-water samples $(0-2 \mathrm{~m})$, which were collected with a Ruttner sampler at $0.5 \mathrm{~m}$ depth in the open-water, mid-lake station in each lake. Water was collected with a Plexiglas sampler and kept cool during transport to the laboratory. Samples were analyzed for alkalinity, and concentrations of $\mathrm{Ca}, \mathrm{Mg}, \mathrm{Na}, \mathrm{K}, \mathrm{SO}_{4}, \mathrm{Cl}, \mathrm{F}, \mathrm{NH}_{4}-\mathrm{N}, \mathrm{NO}_{2}$ $\mathrm{N}+\mathrm{NO}_{3}-\mathrm{N}$, total $\mathrm{N}, \mathrm{PO}_{4}-\mathrm{P}$, total $\mathrm{P}, \mathrm{Si}$, total organic carbon (TOC), and Chlorophyll $a$.

Secchi depth (a measure of water transparency), water temperature, dissolved oxygen concentration, conductivity, and $\mathrm{pH}$ were measured in the lakes. Remaining $\mathrm{P}$ was calculated by subtracting $\mathrm{PO}_{4}-\mathrm{P}$ from total $\mathrm{P}$. These water quality variables helped to delineate lake types, i.e., although limed lakes clearly comprised two treatment groups, we discerned between acidified and circumneutral lakes, chiefly on the basis of their $\mathrm{pH}$, acid neutralizing capacity (ANC), and alkalinity values (Table 1).

Fig. 1. Localization of study lakes. Lake categories: acidified lakes (A; black squares), circumneutral lakes (N; black circles), naturally acidic, limed lakes (NAL; white circles), anthropogenically acidifed, limed lakes (AAL; white squares), $1=$ Ejgdesjön $(\mathrm{NAL}), 2=$ Fräcksjön $(\mathrm{N}), 3=$ Härsvatten $(\mathrm{A}), 4=$ Stora Härsjön (AAL), 5 = Gyltigesjön (AAL), $6=$ Stora Skärsjön (N), 7 = Stengårdshultasjön (AAL), $8=$ Gyslättasjön (NAL), $9=$ Rotehogstjärnen (A), $10=$ Brunnsjön $(\mathrm{A}), 11=$ Allgjuttern $(\mathrm{N}), 12=$ Västra Skälsjön (NAL).

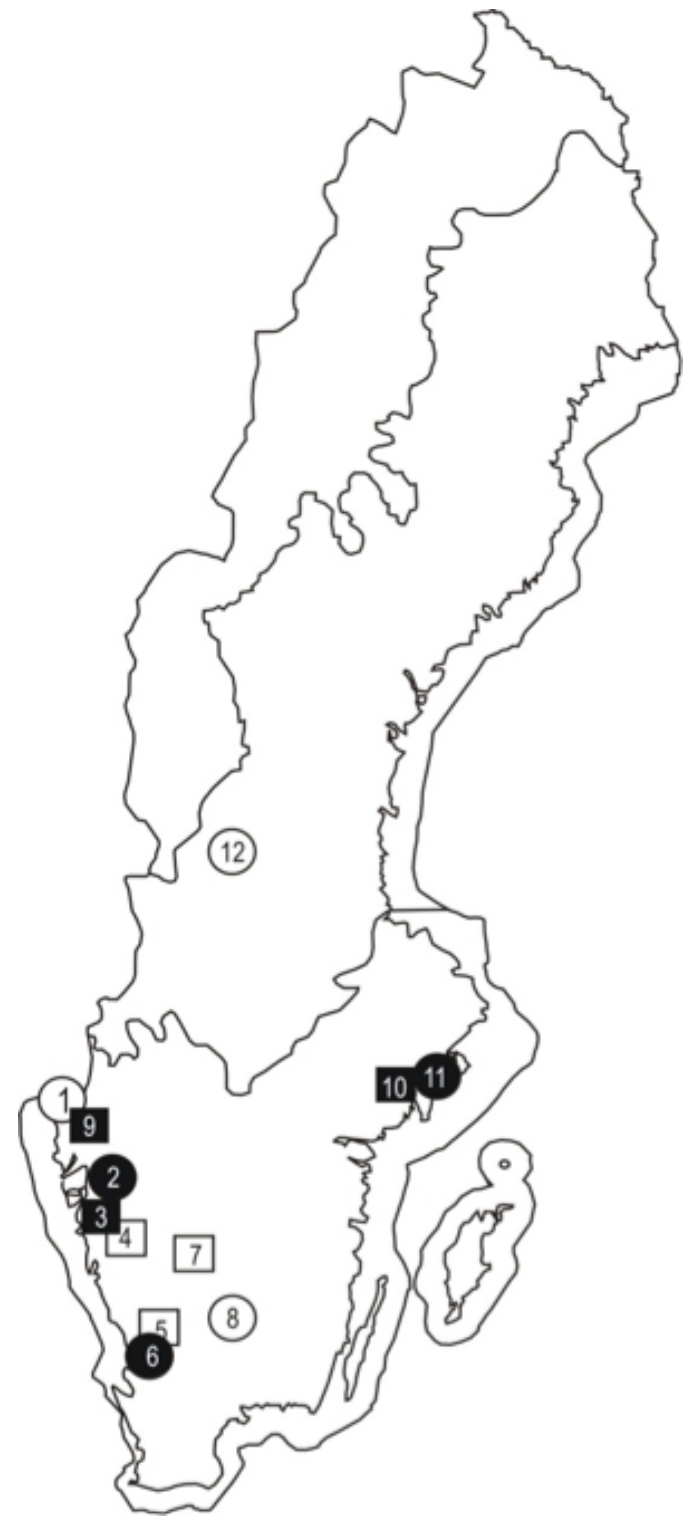


Table 1. Morphological and selected water chemistry characteristics of lakes included in the study. Values represent the interannual mean values based on summer values (August) \pm 1 standard error (italic fonts; $n=5$ ) for the time period 2000-2004. SMHI $=$ Swedish Meteorological and Hydrological Institute.

\begin{tabular}{|c|c|c|c|c|c|c|c|c|c|c|c|c|c|c|c|}
\hline & $\begin{array}{l}\text { SMHI X } \\
\text { SMHI Y }\end{array}$ & $\begin{array}{c}\text { Lake } \\
\text { area } \\
\left(\mathrm{km}^{2}\right)\end{array}$ & $\begin{array}{l}\text { Max, } \\
\text { Depth } \\
\text { (m) }\end{array}$ & $\mathrm{pH}$ & $\begin{array}{l}\text { Alkalinity } \\
\text { meq L }^{-1}\end{array}$ & $\begin{array}{c}\mathrm{Ca} \\
\text { meq } \mathrm{L}^{-1}\end{array}$ & $\begin{array}{c}\mathrm{Mg} \\
\text { meq L }\end{array}$ & $\begin{array}{c}\mathrm{Na} \\
\text { meq L }\end{array}$ & $\begin{array}{c}\mathrm{K} \\
\text { meq } \mathrm{L}^{-1}\end{array}$ & $\mathrm{SO}_{4}$ & $\begin{array}{c}\mathrm{Cl} \\
\text { meq } \mathrm{L}^{-1}\end{array}$ & $\begin{array}{c}\mathrm{F} \\
\mathrm{mg} \mathrm{L}^{-1}\end{array}$ & $\begin{array}{c}\text { TOC } \\
\mathrm{mg} \mathrm{L}^{-1}\end{array}$ & $\begin{array}{l}\mathrm{PO}_{4}-\mathrm{P} \\
\mu \mathrm{g} \mathrm{L} \mathrm{L}^{-1}\end{array}$ & $\begin{array}{c}\mathrm{NO}_{2}+\mathrm{NO}_{3}-\mathrm{N} \\
\mu \mathrm{g} \mathrm{L}^{-13}\end{array}$ \\
\hline \multicolumn{16}{|l|}{ Acidified lakes } \\
\hline \multirow[t]{2}{*}{ Brunnsjön } & 627443 & 0.11 & 10.60 & 5.71 & $<0.01$ & 0.20 & 0.12 & 0.21 & 0.02 & 0.20 & 0.17 & 0.13 & 20.42 & 4.20 & 53.40 \\
\hline & 149526 & & & \pm 0.10 & $\pm<0.01$ & \pm 0.01 & $\pm<0.01$ & $\pm<0.01$ & $\pm<0.01$ & \pm 0.01 & \pm 0.01 & $\pm<0.01$ & \pm 4.51 & \pm 0.86 & \pm 11.13 \\
\hline \multirow[t]{2}{*}{ Härsvatten } & 643914 & 0.19 & 26.20 & 4.84 & -0.02 & 0.03 & 0.06 & 0.24 & 0.01 & 0.09 & 0.26 & 0.03 & 2.38 & 1.40 & 55.00 \\
\hline & 127698 & & & \pm 0.07 & $\pm<0.01$ & $\pm<0.01$ & $\pm<0.01$ & $\pm<0.01$ & $\pm<0.01$ & $\pm<0.01$ & \pm 0.01 & $\pm<0.01$ & \pm 0.23 & \pm 0.24 & \pm 8.22 \\
\hline \multirow[t]{2}{*}{ Rotehogstjärnen } & 652902 & 0.17 & 9.40 & 5.88 & 0.02 & 0.07 & 0.07 & 0.21 & 0.01 & 0.07 & 0.18 & 0.05 & 13.26 & 2.60 & 4.60 \\
\hline & 125783 & & & \pm 0.03 & $\pm<0.01$ & $\pm<0.01$ & $\pm<0.01$ & $\pm<0.01$ & $\pm<0.01$ & $\pm<0.01$ & \pm 0.01 & $\pm<0.01$ & \pm 1.65 & \pm 0.68 & \pm 1.33 \\
\hline \multicolumn{16}{|l|}{ Circumneutral lakes } \\
\hline \multirow[t]{2}{*}{ Allgjuttern } & 642489 & 0.19 & 40.70 & 6.79 & 0.07 & 0.17 & 0.10 & 0.13 & 0.01 & 0.17 & 0.09 & 0.22 & 7.08 & 1.80 & 4.00 \\
\hline & 151724 & & & \pm 0.15 & $\pm<0.01$ & $\pm<0.01$ & $\pm<0.01$ & $\pm<0.01$ & $\pm<0.01$ & \pm 0.01 & $\pm<0.01$ & \pm 0.01 & \pm 0.23 & \pm 0.37 & \pm 1.05 \\
\hline \multirow{2}{*}{ Fräcksjön } & 645289 & 0.28 & 14.50 & 6.68 & 0.08 & 0.17 & 0.09 & 0.26 & 0.02 & 0.10 & 0.26 & 0.07 & 9.42 & 2.40 & 7.60 \\
\hline & 128665 & & & \pm 0.07 & \pm 0.01 & $\pm<0.01$ & $\pm<0.01$ & $\pm<0.01$ & $\pm<0.01$ & $\pm<0.01$ & \pm 0.01 & $\pm<0.01$ & \pm 0.42 & \pm 0.40 & \pm 2.73 \\
\hline \multirow[t]{2}{*}{ St Skärsjön } & 628606 & 0.31 & 11.50 & 6.99 & 0.13 & 0.18 & 0.16 & 0.32 & 0.01 & 0.17 & 0.31 & 0.07 & 5.10 & 1.80 & 4.20 \\
\hline & 133205 & & & \pm 0.08 & \pm 0.01 & $\pm<0.01$ & $\pm<0.01$ & \pm 0.01 & $\pm<0.01$ & \pm 0.01 & \pm 0.01 & $\pm<0.01$ & \pm 0.99 & \pm 0.37 & \pm 1.59 \\
\hline \multicolumn{16}{|c|}{ Naturally acidic, limed lakes } \\
\hline \multirow[t]{2}{*}{ Ejgdesjön } & 653737 & 0.83 & 28.60 & 7.49 & 0.25 & 0.33 & 0.06 & 0.28 & 0.01 & 0.08 & 0.28 & 0.09 & 5.78 & 1.80 & 116.00 \\
\hline & 125017 & & & \pm 0.12 & \pm 0.03 & \pm 0.02 & $\pm<0.01$ & $\pm<0.01$ & $\pm<0.01$ & $\pm<0.01$ & \pm 0.01 & $\pm<0.01$ & \pm 0.75 & \pm 0.58 & \pm 14.52 \\
\hline \multirow[t]{2}{*}{ V. Skälsjön } & 664620 & 0.41 & 18.70 & 7.00 & 0.14 & 0.20 & 0.03 & 0.06 & 0.01 & 0.09 & 0.04 & 0.08 & 12.58 & 1.60 & 3.40 \\
\hline & 148590 & & & \pm 0.15 & \pm 0.02 & \pm 0.01 & $\pm<0.01$ & $\pm<0.01$ & $\pm<0.01$ & $\pm<0.01$ & $\pm<0.01$ & $\pm<0.01$ & \pm 2.37 & \pm 0.40 & \pm 0.51 \\
\hline \multirow[t]{2}{*}{ Gyslättasjön } & 633209 & 0.33 & 9.80 & 6.87 & 0.12 & 0.29 & 0.06 & 0.15 & 0.01 & 0.13 & 0.13 & 0.08 & 12.90 & 1.60 & 4.20 \\
\hline & 141991 & & & \pm 0.06 & \pm 0.01 & \pm 0.01 & $\pm<0.01$ & \pm 0.01 & $\pm<0.01$ & \pm 0.01 & \pm 0.01 & $\pm<0.01$ & \pm 1.01 & \pm 0.24 & \pm 0.92 \\
\hline \multicolumn{16}{|c|}{ Acidified. limed lakes } \\
\hline \multirow[t]{2}{*}{ Gyltigesjön } & 629489 & 0.40 & 20.00 & 7.04 & 0.26 & 0.39 & 0.11 & 0.21 & 0.01 & 0.10 & 0.21 & 0.09 & 15.68 & 5.00 & 154.20 \\
\hline & 133906 & & & \pm 0.10 & \pm 0.03 & \pm 0.03 & \pm 0.01 & \pm 0.01 & $\pm<0.01$ & \pm 0.01 & \pm 0.01 & $\pm<0.01$ & \pm 1.85 & \pm 1.26 & \pm 14.96 \\
\hline \multirow[t]{2}{*}{ Stengårdshultasjön } & 638317 & 4.98 & 26.80 & 7.07 & 0.18 & 0.29 & 0.08 & 0.15 & 0.02 & 0.09 & 0.16 & 0.07 & 10.14 & 2.40 & 53.80 \\
\hline & 138010 & & & \pm 0.04 & \pm 0.01 & \pm 0.01 & $\pm<0.01$ & $\pm<0.01$ & $\pm<0.01$ & $\pm<0.01$ & $\pm<0.01$ & $\pm<0.01$ & \pm 0.43 & \pm 0.75 & \pm 14.37 \\
\hline \multirow[t]{2}{*}{ Stora Härsjön } & 640364 & 2.57 & 42.00 & 7.36 & 0.28 & 0.39 & 0.08 & 0.30 & 0.02 & 0.12 & 0.33 & 0.07 & 4.80 & 1.20 & 133.40 \\
\hline & 129240 & & & \pm 0.12 & \pm 0.01 & \pm 0.01 & $\pm<0.01$ & \pm 0.01 & $\pm<0.01$ & $\pm<0.01$ & \pm 0.01 & $\pm<0.01$ & \pm 0.19 & \pm 0.20 & \pm 15.53 \\
\hline
\end{tabular}

All physicochemical variables were analyzed in certified laboratories at the Department of Aquatic Sciences and Assessment following international (ISO) or European (EN) standards when available (Fölster et al. 2014). Littoral macroinvertebrate samples were collected once in autumn (between September and November) from stony habitats (wind exposed littoral regions) using standardized kick sampling and a handnet (European Committee for Standardization 1994) with a $0.5-\mathrm{mm}$ mesh size, and preserved in $70 \%$ ethanol. Samples of sublittoral and profundal invertebrates were sampled using an Ekman grab (surface area $0.025 \mathrm{~m}^{2}$ ), screened in a $0.5 \mathrm{~mm}$ sieve and preserved in $70 \%$ ethanol. Five replicate samples were collected and biomasses were determined by weighing (ethanol weight); the average of the five replicates was used for analyses. In the laboratory, samples were sorted under $10 \mathrm{x}$ magnification, identified using dissecting and light microscopy. Organisms were identified to the lowest taxonomic unit possible, generally to the species level, although exceptions occurred with some chironomid larvae and immature oligochaetes.

Zooplankton was sampled quantitatively in August using a 55-cm Plexiglas tube (inner diameter, $10 \mathrm{~cm}$ ) equipped with a closing mechanism triggered by a messenger. Samples were generally collected at 2-m intervals from the surface down to 8-m depth. Samples were pooled, screened $(40 \mu \mathrm{m})$, and preserved in acid Lugol's solution. Taxonomic analyses, enumeration, and length measurements were done using an inverted microscope. Biovolumes were calculated from length measurements and known relationships for different taxa, life stages, and/or size classes.

Epilimnetic, integrated samples $(0-4 \mathrm{~m})$ of phytoplankton samples were also collected in August with a tube sampler, usually from 5 sites per lake, pooled and preserved in Lugol's solution. Taxonomic analyses and species enumerations were done under an inverted microscope using the Utermöhl technique (Olrik et al. 1989). Biovolumes were calculated from geometric shapes following Blomqvist and Herlitz (1998).

Sampling of fish communities has been described by Angeler and Goedkoop (2010). Briefly, fish were sampled with Nordic benthic standard multimesh gillnets. A specific number of nets $(n=8-48)$ with random distribution were deployed within specified depth strata, depending on lake area and maximum depth. Length measurements were taken for all individuals, and individual mass was estimated by using species-specific length-mass relationships. No fish data were available for one of the acidified lakes (Lake Härsvatten).

\section{Statistical analyses}

Nonmetric multidimensional scaling (NMDS) was done in Primer v.6 (Primer-E Ltd, Plymouth, UK) to explore the similarity of community trends over the study period across lake types. As a nonlinear technique, NMDS ranks points in ordination space in a 
Fig. 2. Nonmetric multidimensional scaling (MDS) ordinations showing similarities in water quality characteristics between lake types. Shown are also the variables that correlated with the MDS dimensions 1 and 2, and which explained gradients in water quality characteristics in the ordination. The strength of correlation is indicated by the Spearman rank correlation coefficient (rho) and the significance level $(* \mathrm{P}<0.05, * * \mathrm{P}<0.01, * * * \mathrm{P}<0.001)$.

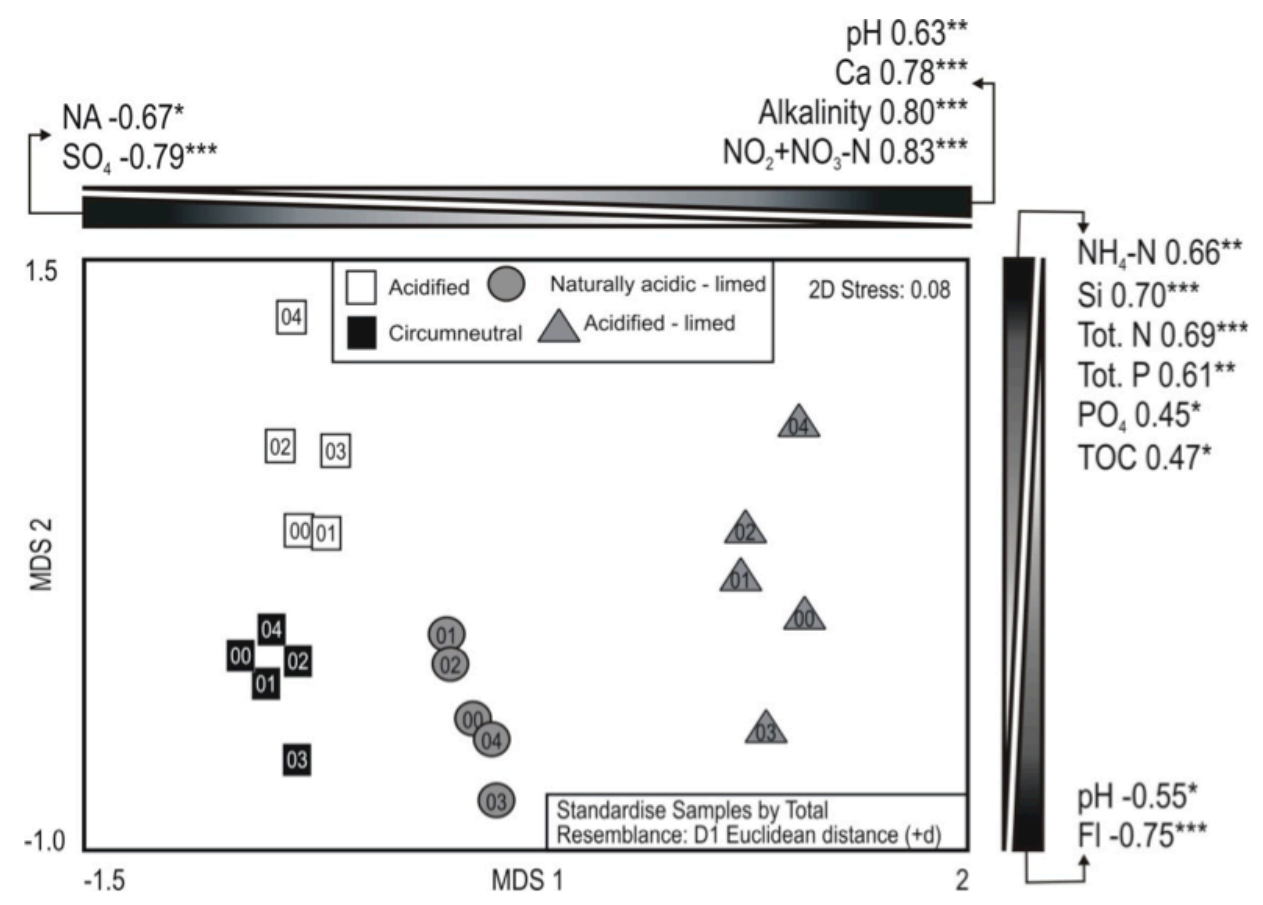

way that the distance between sampling points (in this study aquatic communities) reflects community similarity (ter Braak 1995). The ordination is based on a Bray-Curtis dissimilarity matrix derived from average values of all replicate lakes and log $(x+1)$-transformation of the sample by species matrix. In addition, a NMDS analysis was carried out for water quality; in this case the ordination is based on a Euclidean distance matrix derived from standardized and $\log (\mathrm{x}+1)$-transformed water chemistry data, including Secchi depth, water temperature, dissolved oxygen concentration, conductivity, $\mathrm{pH}$, alkalinity, and concentrations of $\mathrm{Ca}, \mathrm{Mg}, \mathrm{Na}, \mathrm{K}, \mathrm{SO}_{4}, \mathrm{Cl}, \mathrm{F}, \mathrm{NH}_{4}-\mathrm{N}, \mathrm{NO}_{2}-\mathrm{N}+$ $\mathrm{NO}_{3}-\mathrm{N}$, total $\mathrm{N}, \mathrm{PO}_{4}-\mathrm{P}$, total $\mathrm{P}$, remaining $\mathrm{P}$ (total $\left.\mathrm{P}-\mathrm{PO}_{4}-\mathrm{P}\right), \mathrm{Si}$, total organic carbon (TOC), and Chlorophyll $a$. The final solutions for each community and the water quality analysis are based on 999 reruns.

Analysis of Similarity (ANOSIM; 999 reruns) was also carried out in Primer to test if significant differences in biomass/ abundance of communities occurred among lake types. This analysis uses the $\mathrm{R}$ statistic to test differences between groups $(\mathrm{R}$ $=0$, no differences; $\mathrm{R}=1$, all dissimilarities between groups are larger than all dissimilarities within groups). In the present study, the ANOSIM analysis was used to complement the NMDS analyses. We calculated the yearly average for each lake type, which resulted in 5 replicates (5 study years) $\mathrm{x} 4$ lake types (acidified, circumneutral, acidified limed, naturally acidic limed) $=20$ samples for the analysis. Similarity Percentage routine (SIMPER; also included in Primer v.6) was used to reveal which taxa contributed to dissimilarity between lake types.

\section{RESULTS}

Lake characteristics and water quality

Most of the lakes had a surface area $<1 \mathrm{~km}^{2}$, but some lakes were up to 5-times larger, Brunnsjön was the smallest lake $\left(0.11 \mathrm{~km}^{2}\right)$ while Stengårdshultasjön was the largest $\left(4.98 \mathrm{~km}^{2}\right.$; Table 1$)$. The lakes also showed a depth gradient, with the acidified lake Rotehogstjärnen being the shallowest $\left(Z_{\max }=9.4 \mathrm{~m}\right)$ and the acidified limed Stora Härsjön being the deepest $\left(Z_{\max }=42 \mathrm{~m}\right)$. With regard to trophic state characteristics acidified, circumneutral, acidified limed and naturally acidic limed lakes showed average total $\mathrm{P}$ concentrations of $8,11,11$, and $8 \mu \mathrm{g} \mathrm{L}^{-1}$, respectively, and average total $\mathrm{N}$ concentrations of $386,452,465$, and $381 \mu \mathrm{g} \mathrm{L}^{-1}$, respectively. Differences in water quality were observed among lake types with regard to variables that are most affected by acidification and liming treatments. For example, the mean $\mathrm{pH}$ of acidified lakes was always below 6 , while circumneutral lakes showed an average $\mathrm{pH}$ value of 6.8 . The two types of limed lakes showed a $\mathrm{pH}>7.0$. The integral analysis of water quality using multivariate statistics showed that water chemistry in the different lake types clusters distinctly in ordination space (Fig. 2), and an analysis of similarity showed significant differences in water quality between lake categories (ANOSIM: global $\mathrm{R}=0.903, \mathrm{P}<0.001$ ).

Relating water chemistry variables to the NMDS dimension through Spearman rank correlation analyses revealed gradients in the abiotic environment that help understand the organization of lake types in multivariate ordination space. Lake groups were 
Table 2. ANOSIM analysis showing global results and pairwise comparison between lake types (NA-L, naturally acidic-limed; AA-L, acidified-limed; acid, acidified; neutral, circumneutral). Shown are R statistics and significance levels. Significant P values are highlighted in bold.

\begin{tabular}{|c|c|c|c|c|c|c|c|c|c|c|c|c|}
\hline \multirow[b]{2}{*}{ Groups } & \multicolumn{2}{|c|}{ Phytoplankton } & \multicolumn{2}{|c|}{ Zooplankton } & \multicolumn{2}{|c|}{ Littoral Inv. } & \multicolumn{2}{|c|}{ Sublittoral Inv. } & \multicolumn{2}{|c|}{ Profundal Inv. } & \multicolumn{2}{|c|}{ Fish } \\
\hline & $\mathrm{R}$ & $\mathrm{P}$ & $\mathrm{R}$ & $\mathrm{P}$ & $\mathrm{R}$ & $\mathrm{P}$ & $\mathrm{R}$ & $\mathrm{P}$ & $\mathrm{R}$ & $\mathrm{P}$ & $\mathrm{R}$ & $\mathrm{P}$ \\
\hline Global analysis & 0.880 & 0.001 & 0.240 & 0.001 & 0.240 & 0.001 & 0.153 & 0.001 & 0.036 & 0.173 & 0.294 & 0.001 \\
\hline NA-L x AA-L & 0.888 & 0.008 & 0.035 & 0.174 & 0.120 & 0.019 & 0.174 & 0.004 & 0.047 & 0.109 & 0.439 & 0.001 \\
\hline NA-L x Acid & 0.808 & 0.008 & 0.284 & 0.001 & 0.511 & 0.001 & 0.204 & 0.004 & 0.035 & 0.164 & 0.339 & 0.002 \\
\hline NA-L x Neutral & 1.000 & 0.008 & 0.409 & 0.001 & 0.147 & 0.036 & 0.033 & 0.248 & 0.074 & 0.135 & 0.509 & 0.001 \\
\hline AA-L x Acid & 0.992 & 0.008 & 0.221 & 0.001 & 0.474 & 0.001 & 0.350 & 0.001 & 0.099 & 0.054 & 0.256 & 0.004 \\
\hline AA-L x Neutral & 0.794 & 0.008 & 0.208 & 0.002 & 0.061 & 0.161 & 0.056 & 0.167 & 0.003 & 0.428 & 0.184 & 0.012 \\
\hline Acid x Neutral & 0.969 & 0.008 & 0.297 & 0.001 & 0.267 & 0.001 & 0.222 & 0.001 & 0.033 & 0.209 & 0.182 & 0.014 \\
\hline
\end{tabular}

separated along NMDS 1 as a function of variables that clearly captured the management (liming) intervention on one hand, but also nutrient conditions on the other hand. Both types of limed lakes were characterized by higher concentrations of $\mathrm{Ca}$ and $\mathrm{NO}_{2}+\mathrm{NO}_{3}-\mathrm{N}$, a higher alkalinity and $\mathrm{pH}$, and lower concentrations of $\mathrm{Na}$ and $\mathrm{SO}_{4}$ relative to acidified and circumneutral lakes (Fig. 2). Along NMDS 2, gradients in the acidity and nutrient status helped explain the observed patterns. Culturally acidified limed lakes showed lower $\mathrm{pH}$ values relative to the other lake groups. Acidified limed lakes showed a wider spread of sampling dates along NMDS 2. Similar trends were observed regarding nutrient conditions $\left(\mathrm{NH}_{4}\right.$, total $\mathrm{P}$, total $\mathrm{N}$, $\mathrm{PO}_{4}$ ) and water color (TOC), with acidified lakes clearly deviating from circumneutral and culturally acidified limed lakes, and with naturally acidic limed lakes occupying intermediate positions.

\section{Community structure}

Nonmetric multidimensional scaling analyses based on community structure showed that the phytoplankton, zooplankton, macroinvertebrate (in three habitat types; littoral, sublittoral, profundal) and fish communities formed distinct clusters in ordination space, based on lake type (circumneutral, acidified, acidified limed, naturally acidic limed; Fig. 3). Overall comparison of community structure in the ANOSIM showed significant differences in community structure, except profundal macroinvertebreates (Table 2). Pairwise comparisons revealed significant differences between all lake types for phytoplankton and fish (Table 2). For zooplankton all comparisons were significant except those of the limed lakes (naturally acidic $\mathrm{x}$ culturally acidified; Table 2). For littoral macroinvertebrates, only the acidified limed $\mathrm{x}$ circumneutral lake comparison was not significant. For sublittoral maroinvertebrates, acidified limed $\mathrm{x}$ circumneutral, and naturally acidic limed x circumneutral lake comparisons were not significant (Table 2).

\section{Taxonomic contributions to community similarity}

Detailed results from the similarity percentage (SIMPER) analyses, which revealed that the different lake types differed in terms of species occurrences and their numerical dominance within the communities, are summarized in Appendix 1. An overview of the main findings will be presented separately for each community studied.

Phytoplankton: $35,19,37$, and 36 taxa contributed to explain $90 \%$ of community structure in circumneutral, acidified, acidified limed, and naturally acidic limed lakes, respectively.
Fig. 3. Nonmetric multidimensional scaling (MDS) ordinations showing similarities in community structure of phytoplankton, zooplankton, macroinvertebrates in three habitat types (littoral, sublittoral, profundal) and fish between lake types. Stress values $<0.15$ means reliable ordination solutions.

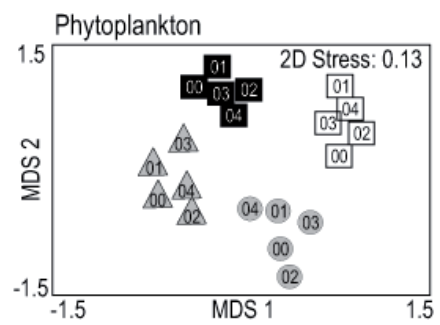

Zooplankton

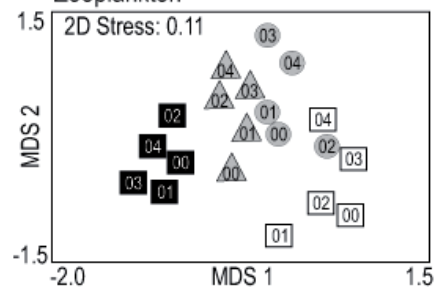

Littoral macroinvertebrates

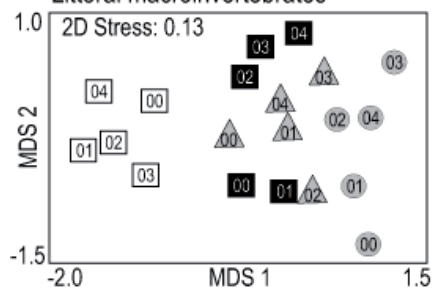

Sublittoral macroinvertebrates

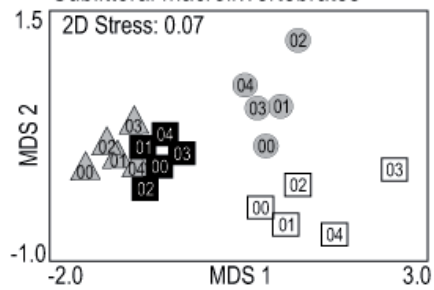

Profundal macroinvertebrates
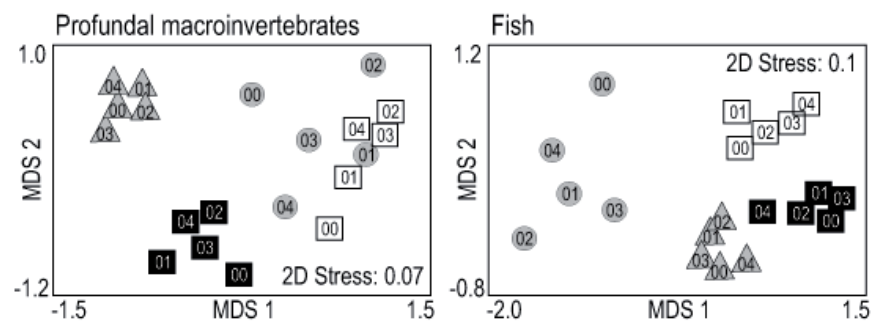

Lakes:

$\square$ Acidified $\square$ Circumneutral $\bigcirc$ Naturally acidic - limed $\triangle$ Acidified - limed

Circumneutral lakes had an even contribution of taxa to community structure with Cryptomonas spp. (Cryptophyta; size fraction $20-40 \mu \mathrm{m}$ ) contributing $\sim 7 \%$ to community similarity and the remaining species $<5 \%$ (Appendix 1). In acidified lakes, the raphidophycean flagellate, Gonyostomum semen, dominated the phytoplankton community ( $25 \%$ ), followed by Cryptomonas $\mathrm{sp}$. (size fraction $20-40 \mu \mathrm{m}$ ). The remaining species contributed with 
$<6 \%$ to community similarity in acidified lakes (Appendix 1). In acidified limed lakes, an even phytoplankton community was observed with Aulacoseira alpigena (Bacillariophyceae; 5\%), Cryptomonas sp. (size fraction $<20 \mu \mathrm{m} ; \sim 5 \%$ ), Rhodomonas lacustris (Cryptophyceae; $\sim 6 \%$ ), and Tabellaria flocculosa var. asterionelloides (Bacillariophyceae; 5\%) being those with highest percentage contribution to community structure. In naturally acidic limed lakes $G$. semen was dominant $(\sim 25 \%)$, while the remaining species contributed on average less than $3.5 \%$.

Zooplankton: $13,11,12$, and 9 taxa explained $90 \%$ of community structure in circumneutral, acidified, acidified limed, and naturally acidic limed lakes, respectively. In circumneutral lakes, the crustaceans Eubosmina coregoni ( 21\%), Daphnia sp. $(\sim 18 \%)$, and Daphnia cristata $(\sim 14 \%)$ dominated the zooplankton communities. The remaining species contributed with less than $7 \%$ to community structure (Appendix 1). In acidified lakes, the rotifer Asplanchna priodonta contributed most to community similarity $(\sim 33 \%)$, followed by Eubosmina coregoni $(\sim 15 \%)$ and Ceriodaphnia quadrangula $(\sim 10 \%)$. The remaining species contributed $<9 \%$ to zooplankton community structure in these lakes (Appendix 1). In acidified lakes that were limed Asplanchna priodonta ( 22\%), Daphnia sp., and Eubosmina coregoni (both $\sim 15 \%$ ) were the most abundant species, with the others contributing less than $6 \%$ to community structure in this lake type (Appendix 1). In naturally acidic lakes that were limed, Asplanchna priodonta ( 28\%), Ceriodaphnia quadrangula $(\sim 15 \%)$, and Eubosmina coregoni $(\sim 10 \%)$ dominated the zooplankton communities, with the remaining species explaining on average below $10 \%$ of community structure in these lakes (Appendix 1).

Littoral macroinvertebrates: $34,27,28$, and 31 taxa explained $90 \%$ of community structure in circumneutral, acidified, acidified limed, and naturally acidic limed lakes, respectively. Asellus aquaticus (Crustacea) was numerically dominant in all lake types ( 10-13\%; Appendix 1), Leptophlebia vespertina (Ephemeroptera) was also dominant in acidified and acidified limed lakes $(\sim 16-$ $18 \%$, while in naturally acidic limed lakes Caenis luctuosa (Ephemeroptera; < 10\%) was important (Appendix 1). The remaining species differed in their incidence patterns and abundance patterns between lake types. Although their percentage contribution to community structure was generally not high, the subtle differences observed at the individual taxon level (Appendix 1) resulted in significantly different community structures between lake types when aggregate analysis on all taxa are carried out.

Sublittoral macroinvertebrates: 7, 4, 6, and 9 taxa explained $90 \%$ of community structure in circumneutral, acidified, acidified limed, and naturally acidic limed lakes, respectively. Valvata piscinata (> 30\%) and Chaoborus flavicans (Diptera; 14-31\%) dominated in all lake types (Appendix 1). Ceratopogonidae (Diptera) were also abundant in acidified lakes and naturally acidic limed lakes (18 and 14\%, respectively), Physa fontinalis (Mollusca), Athripsodes sp., (Trichoptera) and Anisoptera were also important in acidified lakes $(<10 \%)$ (Appendix 1).

Profundal macroinvertebrates: 3, 2, 5, and 2 taxa explained $90 \%$ of community structure in circumneutral, acidified, acidified limed, and naturally acidic limed lakes, respectively. Dominance was reached by the phantom midge, Chaoborus flavicans, in circumneutral, acidified limed and naturally acidic limed lakes
(62-81\%; Appendix 1). In these lakes Chironomidae and Oligochaeta were the only broad taxonomic groups that explained some additional structure of the profundal macroinvertebrate communities (Appendix 1). Only in acidified limed lakes were more even communities observed, with Bivalvia contributing to community structure in addition to Chironomidae, Oligochaeta, and Chaoborus flavicans (Appendix 1).

Fish: 6, 4, 5, 3 taxa explained $90 \%$ of community structure in circumneutral, acidified, acidified limed, and naturally acidic limed lakes, respectively. All lakes were dominated by Perca fluviatilis $(>30 \%)$ and Leuciscus rutilus $(>21 \%)$, Salvelinus alpinus occurred only in naturally acidic limed lakes, Abramis brama and Esox lucius contributed to different degrees to community structure in circumneutral, acidified, and acidified limed lakes, while these species were absent in naturally acidic limed lakes (Appendix 1).

\section{DISCUSSION}

Environmental monitoring programs, despite being extremely useful for assessing trends in ecological patterns, are often faced with constraints that can affect experimental designs and inference (Downes et al. 2002). For instance, the limed lakes used in the monitoring program deviate in their morphometric and biological settings and only comprise a small sample from a large number of Swedish lakes that undergo liming treatment (Holmgren and Fölster 2010). Also, naturally acidic lakes with time periods before and after liming are not included in the monitoring. Despite limitations, our results support the hypothesis that liming causes ecological impacts in lakes that can be scrutinized from a structural perspective. These structural changes have implications for ecosystem service provisioning and the resilience of boreal lakes.

Desired outcomes of liming are measured with the reestablishment of acid-sensitive species of conservation interest, e.g., crayfish, freshwater pearl mussel, roach, charr, and salmon (Holmgren et al. 2016). The results of this study suggest that the attainment of such management goals, and the social benefits that ensue, for instance those related to recreational fisheries, can be confounded. One of the naturally acidic limed lakes (Västra Skälsjön) was located in a different ecoregion in Sweden, relative to the rest of the lakes. The observation of Arctic charr, (Salvelinus alpinus), dominating the fish community in Västra Skälsjön, is therefore most likely confounded by a biogeographical signal and not resulting from liming. This suggests that the ecosystem services provided by this fish species, e.g., recreational fisheries, can be unrelated to liming. Also, the absence of pike (Esox lucius), another species of interest to anglers, was not present in naturally acidic limed lakes, which further suggests that these lakes do not create the fisheries potential that is often targeted with liming management.

Another management goal of liming is to achieve and maintain biodiversity (Angeler and Goedkoop 2010). In a previous study no significant differences were found comparing univariate biodiversity measures among naturally acidic limed lakes and reference lakes (Angeler et al. 2010). These results suggest that accidental liming of naturally acidic lakes achieves these management goals. This study, however, revealed significant differences across taxonomic groups among lake types. Contrary to previous findings, this suggests that liming of naturally acidic 
and culturally acidified lakes creates species assemblages, which differ from those in acidified and circumneutral references. Given that these communities arise from strong management interventions, they might be regarded as artificial and not representative of the boreal lake landscape. In this study we used multivariate analyses, which integrate all taxonomic information in the analysis, compared to the univariate analysis in which the taxonomic structure is lost during metric calculation. Multivariate analysis can therefore perform better in pattern and impact detection compared to univariate analyses (Angeler and Goedkoop 2010, Spanbauer et al. 2014).

A further finding of this study is that naturally acidic limed lakes were dominated by the flagellate Gonyostomum semen, a species that is also common in the acidified lakes in this study and others (Angeler et al. 2012). This alga is an undesired species because it forms blooms that decrease water quality and increase maintenance costs for water treatment (Cronberg et al. 1988). Also Gonsyostomum can cause skin rashes and therefore reduces the bathing quality of lakes (Hongve et al. 1988). The patterns of Gonyostomum distribution and abundance are strongly associated with light conditions in the lakes (Appendix 2). Liming as a management strategy seems to increase organic carbon of naturally brown acidic lakes to higher concentrations, thereby intensifying their heterotrophic conditions. In turn, these conditions favor Gonyostomum, which has a saprotrophic (combined heterotrophic and autotrophic) feeding mode. Our analysis suggests that accidental liming of lakes can alter geochemical conditions that can be undesired ecologically.

There are currently arguments that speak against liming, based on assumptions that an ecosystems' natural disturbance regime is altered (Bishop et al. 2001, McKie et al. 2006). In a more specific management context, our results support the notion that accidental liming of naturally acidic lakes may comprise some form of command and control management (Holling and Meffe 1996). Liming generated substantial negative side effects in the ecosystem because of biogeochemical alteration without achieving desired outcomes in terms of targeted increase in biodiversity and habitat suitability to sustain fisheries. We currently lack information on how strong and persistent continued liming effects are on wider ecosystem patterns and processes in the long term. It is also uncertain if liming leaves an ecological legacy and how it will manifest in lakes if liming has been discontinued. It can therefor currently not be estimated to what degree liming of naturally acidic lakes creates conditions that would qualify as novel ecosystems (Hobbs et al. 2009), that is, a form of engineered systems with altered structure and function without natural analogue. If accidental liming fundamentally alters the equilibrium conditions of naturally acidic systems that become self-sustaining, further research will be required to foster our understanding of potentially negative side effects on the ecological integrity of managed lakes (Baho et al. 2014).

Our results suggest that future research is warranted to explore management trade-offs because liming is not only ecologically relevant but also in societies' best interest. Liming comprises a strongly coupled social-ecological system with governmental investments amounting roughly to $€ 31$ million each year (Karlsson 2013). Important socioeconomic benefits derive from liming for instance with recreational fisheries. Alone in 2013 recreational finishing generated expenditures of approximately $€ 5$ million and $\sim 9000$ t of harvest were landed inland (HaV 2013). Liming thus plays a role for creating jobs and revenue. We currently lack the data that would allow for an exhaustive socialecological analysis to determine the trade-offs between the pathological outcomes of liming naturally acidic lakes observed in this study and the social benefits that derive in terms of ecosystem service provisioning. Adaptive management and scenario planning have been suggested as alternative tools to command and control approaches to minimize pathological management outcomes and improve ecosystem service provisioning and system resilience (Rodríguez et al. 2006, Pope et al. 2014). Adaptive management and scenario planning can fill knowledge gaps in impact assessment and inform institutions to manage the liming of social-ecological systems for resilience.

Responses to this article can be read online at: http://www.ecologyandsociety.org/issues/responses. $\mathrm{php} / 9794$

\section{Acknowledgments:}

This work has been supported by the IKEU liming monitoring program financed by the Swedish Agency for Marine and Water Management (HaV). Additional support was provided by the Swedish Research Councils FORMAS (2014-1193) and VR (2014-5828). The comments of two anonymous referees helped improve this paper.

\section{LITERATURE CITED}

Angeler, D. G., C. R. Allen, and R. K. Johnson. 2012. Insight on invasions and resilience derived from spatiotemporal discontinuities of biomass at local and regional scales. Ecology and Society 17(2):32. http://dx.doi.org/10.5751/ES-04928-170232

Angeler, D. G., and W. Goedkoop. 2010. Biological responses to liming in boreal lakes: an assessment using plankton, macroinvertebrate and fish communities. Journal of Applied Ecology 47:478-486. http://dx.doi.org/10.1111/j.1365-2664.2010.01794. $\underline{x}$

Angeler, D. G., R. K. Johnson, and W. Goedkoop. 2010. Understanding the role of lake history in liming management: a structural and functional comparison of multiple communities. Report 18. Swedish University of Agricultural Sciences. Department of Aquatic Sciences and Assessment, Uppsala, Sweden.

Appelberg, M. and E. Degerman. 1991. Development and stability of fish assemblages after lime treatment. Canadian Journal of Fisheries and Aquatic Sciences 48:546-554. http://dx. doi.org/10.1139/f91-069

Appelberg, M., and T. Svenson. 2001. Long-term ecological effects of liming - The ISELAW programme. Water, Air, and Soil Pollution 130:1745-1750. http://dx.doi.org/10.1007/978-94-007-$\underline{0810-5138}$ 
Baho, D. L., S. Drakare, R. K. Johnson, C. R. Allen, and D. G. Angeler. 2014. Similar resilience attributes in lakes with different management practices. PLoS ONE 9(3):e91881. http://dx.doi. org/10.1371/journal.pone.0091881

Bengtsson, B., and B. Bogelius, A. 1995. Socio-economic consequences of aquatic liming. Pages 423-458 in L. Henrikson and Y. W. Brodin, editors. Liming of acidified surface waters: a Swedish synthesis. Springer, Berlin, Germany. http://dx.doi. org/10.1007/978-3-642-79309-7 18

Binks, J. A., S. E. Arnott, and W. G. Sprules. 2005. Local factors and colonist dispersal influence crustacean zooplankton recovery from cultural acidification. Ecological Applications 15:2025-2036. http://dx.doi.org/10.1890/04-1726

Bishop. K., H. Laudon, J. Hruska, P. Kram, S. Köhler, and S. Löfgren. 2001. Does acidification policy follow research in northern Sweden? The case of natural acidity during the 1990's. Water, Air, and Soil Pollution 130:1415-1420. http://dx.doi. org/10.1023/A:1013936224549

Blomqvist, P., and E. Herlitz. 1998. Methods for quantitative assessment of phytoplankton in freshwaters, part 2. Report 4861. Naturvårdsverket, Stockholm, Sweden.

Clair, T. A. and A. Hindar. 2005. Liming for the mitigation of acid rain effects in freshwaters: a review of recent results. Environmental Reviews 13:91-128. http://dx.doi.org/10.1139/ $\underline{\mathrm{a} 05-009}$

Cronberg, G., G. Lindmark, and S. Björk. 1988. Mass development of the flagellate Gonyostomum semen (Raphidophyta) in Swedish forest lakes - an effect of acidification? Hydrobiologia 161:217-236. http://dx.doi.org/10.1007/BF00044113

Downes, B. J., L. A. Barmutta, P. G. Fairweather, D. P. Faith, M. J. Keough, P. S. Lake, B. D. Mapstone, and G. P. Quinn. 2002. Monitoring ecological impacts: concepts and practice in flowing waters. Cambridge University Press, Cambridge, UK. http://dx. doi.org/10.1017/CBO9780511542015

European Committee for Standardization. 1994. Water qualitymethods for biological sampling and guidance on handnet sampling of aquatic benthic macroinvertebrates. European Committee for Standardization, Brussels, Belgium.

Fischer, J. M., J. L. Klug, A. R. Ives, and T. M. Frost. 2001. Ecological history affects zooplankton community responses to acidification. Ecology 82:2984-3000. http://dx.doi.org/10.1890/0012-9658 (2001)082[2984:EHAZCR]2.0.CO;2

Fölster, J., C. Andrén, K. Bishop, I. Buffam, N. Cory, W. Goedkoop, K. Holmgren, R. K. Johnson, H. Laudon, and A. Wilander. 2007. A novel environmental quality criterion for acidification in Swedish lakes - an application of studies on the relationship between biota and water chemistry. Water, Air and Soil Pollution: Focus 7:331-338. http://dx.doi.org/10.1007/ s11267-006-9075-9

Fölster, J., R. K. Johnson, M. N. Futter, and A. Wilander. 2014. The Swedish monitoring of surface waters: 50 year of adaptive monitoring. Ambio 43:3-18. http://dx.doi.org/10.1007/s13280-014-0558$\underline{z}$
HaV (Swedish Agency for Marine and Water Management). 2013. Statistics on recreational fishing. HaV, Gothenburg, Sweden. [online] URL: https://www.havochvatten.se/en/swam/ facts--leisure/statistics-on-fishing.html

Henrikson, L., and Y. W. Brodin. 1995. Liming of acidified surface waters: a Swedish synthesis. Springer, Berlin, Germany. http://dx. doi.org/10.1007/978-3-642-79309-7

Hobbs, R. J., E. Higgs, and J. A. Harris. 2009. Novel ecosystems: implications for conservation and restoration. Trends in Ecology and Evolution 24(11):599-605. http://dx.doi.org/10.1016/j. tree.2009.05.012

Holling C. S., and G. K. Meffe. 1996. Command and control and the pathology of natural resource management. Conservation Biology 10:328-337. http://dx.doi.org/10.1046/j.1523-1739.1996.10020328. $\underline{\mathrm{X}}$

Holmgren, K., E. Degerman, E. Petersson, and B. Bergquist. 2016. Long-term trends of fish after liming of Swedish streams and lakes. Atmospheric Environment 146:245-251. http://dx.doi. org/10.1016/j.atmosenv.2016.08.033

Holmgren, K., and J. Fölster. 2010. Biologisk och vattenkemisk variation $i$ kalkningsverksamhetens målsjöar - ett förbättrat underlag för bedömning av IKEU-sjöarnas representativitet. Rapport 2010:11. Institutionen för vatten och miljö, Swedish University of Agricultural Sciences, Uppsala, Sweden.

Hongve, D., O. Lovstad, and K. Bjorndalen. 1988. Gonyostomum semen - a new nuisance to bathers in Norwegian lakes. Verhandlungen der internationalen Vereinigung für theoretische und angewandte Limnologie 23:430-434.

Karlsson, R. 2013. The Swedish liming operation. Thesis. Department of Aquatic Sciences and Assessment, Swedish University of Agricultural Sciences, Uppsala, Sweden. [online] URL: http://stud.epsilon.slu.se/6371/

McKie, B. G., Z. Petrin, and B. Malmqvist. 2006. Mitigation or disturbance? Effects of liming on macroinvertebrate assemblage structure and leaf-litter decomposition in the humic streams of northern Sweden. Journal of Applied Ecology 43:780-791. http:// dx.doi.org/10.1111/j.1365-2664.2006.01196.x

Norberg, M., C. Bigler, and I. Renberg. 2008. Monitoring compared with paleolimnology: implications for the definition of reference condition in limed lakes in Sweden. Environmental Monitoring and Assessment 146:295-308. http://dx.doi.org/10.1007/ $\underline{\text { s10661-007-0081-9 }}$

Olrik, K. P., P. Blomqvist, P. Brettum, G. Cronberg, and P. Eloranta. 1989. Methods for quantitative assessment of phytoplankton in freshwaters, Part I. Swedish Environmental Protection Agency, Stockholm, Sweden.

Persson, G., and M. Appelberg. 2001. Evidence of lower productivity in long term limed lakes as compared to unlimed lakes of similar pH. Water, Air, and Soil Pollution 130:1769-1774. http://dx.doi.org/10.1007/978-94-007-0810-5 142

Pope, K. L., C. R. Allen, and D. G. Angeler. 2014. Fishing for resilience. Transactions of the American Fisheries Society 43 (2):467-478. http://dx.doi.org/10.1080/00028487.2014.880735 
Renberg, I., and H. Hultberg. 1992. A paleolimnological assessment of acidification and liming effects on diatom assemblages in a Swedish lake. Canadian Journal of Fisheries and Aquatic Sciences 49:65-72. http://dx.doi.org/10.1139/f92-007

Rodríguez, J. P., T. D. Beard, Jr., E. M. Bennett, G. S. Cumming, S. Cork, J. Agard, A. P. Dobson, and G. D. Peterson. 2006. Tradeoffs across space, time, and ecosystem services. Ecology and Society 11(1):28. http://dx.doi.org/10.5751/ES-01667-110128

Sandoy, S., and A. J. Romunstad. 1995. Liming of acidified lakes and rivers in Norway: an attempt to preserve and restore biological diversity in the acidified regions. Water, Air, and Soil Pollution 85:997-1002. http://dx.doi.org/10.1007/BF00476960

Schindler, D. W. 1988. Effects of acid rain on freshwater ecosystems Science 239:149-157. http://dx.doi.org/10.1126/ $\underline{\text { science.239.4836.149 }}$

Spanbauer, T., C. R. Allen, D. G. Angeler, T. Eason, S. C. Fritz, A. S. Garmestani, K. L. Nash, and J. R. Stone. 2014. Prolonged instability prior to a regime shift. PLOS ONE 9(10):e108936. http://dx.doi.org/10.1371/journal.pone.0108936

Stenson, J. A. E., and J.-E. Svensson. 1995. Changes of planktivore fauna and development of zooplankton after liming of the acidified Lake Gårdsjön. Water, Air, and Soil Pollution 85:979-984. http://dx.doi.org/10.1007/BF00476957

Swedish Environmental Protection Agency (SEPA). 2007. Economic instruments in environmental policy. Report 5678. SEPA (Naturvårdsverket), Stockholm, Sweden. [online] URL: $\underline{\text { http:// }}$ www.naturvardsverket.se/Documents/publikationer/620-5678-6.pdf

ter Braak, C. J. F. 1995. Ordination. Pages 91-173 in R. Jongman, C. J. F. ter Braak, O. F. R. Van Tongeren, editors. Analysis in community and landscape ecology. Cambridge University Press, Cambridge, UK.

Van der Wurff, A. W. G., S. A. E. Kools, M. E. Y. Boivin, P. J. Van den Brink, H. H. M. van Megen, J. A. G. Riksen, A. Doroszuk, and J. E. Kammenga. 2007. Type of disturbance and ecological history determine structural stability. Ecological Applications 17 (1):190-202. http://dx.doi.org/10.1890/1051-0761(2007)017[0190: TODAEH]2.0.CO;2

Yan, N. D., B. Leung, W. Keller, S. E. Arnott, J. M. Gunn, and G. G. Raddum. 2003. Developing conceptual frameworks for the recovery of aquatic biota from acidification. Ambio 32:165-169. http://dx.doi.org/10.1579/0044-7447-32.3.165 


\section{Appendix 1}

Table A1.1: Results from Similarity Percentages (SIMPER) Analyses showing percentage contributions of phytoplankton, zooplankton, macroinvertebrate (in three habitat types; littoral, sublittoral, profundal) and fish to community composition in four different lake types (naturally acidic with liming, anthropogenically acidified with liming, acidified lakes without liming, and circumneutral), - means that the taxa were not contributing to community structure considering a 90\% cut-off level in the analyses (i.e., only taxa are shown that explained $90 \%$ of community structure). Taxa that dominate in each lake type are highlighted in bold.

\begin{tabular}{|c|c|c|c|c|}
\hline & \multicolumn{4}{|c|}{ Lake types } \\
\hline Species & $\begin{array}{l}\text { Naturally } \\
\text { acidic - } \\
\text { limed }\end{array}$ & $\begin{array}{l}\text { Acidified } \\
\text { - limed }\end{array}$ & Acidified & Circumneutral \\
\hline Phytoplankton & & & & \\
\hline Anabaena planctonica & - & 0.67 & - & - \\
\hline Asterionella formosa & 0.83 & 1.76 & - & - \\
\hline Aulacoseira alpigena & - & 5.19 & - & 3.83 \\
\hline Aulacoseira distans & - & 3.64 & - & - \\
\hline $\begin{array}{l}\text { Aulacoseira distans } \\
\text { var. tenella }\end{array}$ & - & 1.41 & 3.68 & - \\
\hline Bicosoeca sp. & - & - & 1.05 & - \\
\hline $\begin{array}{l}\text { Botryococcus } \\
\text { terribilis }\end{array}$ & - & - & 5.32 & 4.84 \\
\hline
\end{tabular}




\begin{tabular}{|c|c|c|c|c|}
\hline Botryococcus spp. & 2.5 & 1.32 & - & - \\
\hline Ceratium furcoides & 2.29 & 3.74 & - & - \\
\hline Ceratium hirundinella & 1.94 & - & - & 2.63 \\
\hline $\begin{array}{l}\text { Chlamydomonas spp. } \\
5-10 \mu \mathrm{m}\end{array}$ & 0.83 & - & - & - \\
\hline $\begin{array}{l}\text { Other unidentified } \\
\text { Chlorococcales }\end{array}$ & 1.83 & 2.17 & 3.54 & 2.79 \\
\hline Chroococcus minutus & 0.8 & - & - & 1.24 \\
\hline $\begin{array}{l}\text { Chrysidiastrum } \\
\text { catenatum }\end{array}$ & 1.52 & 1.53 & - & - \\
\hline $\begin{array}{l}\text { Chrysochromulina } \\
\text { parva }\end{array}$ & 2.06 & 3.74 & - & 2.84 \\
\hline Chrysococcus sp. & 1.02 & 0.8 & - & - \\
\hline $\begin{array}{l}\text { Cosmarium spp. }<10 \\
\mu \mathrm{m}\end{array}$ & - & - & - & 1.38 \\
\hline $\begin{array}{l}\text { Cryptomonas } \\
\text { marssonii }<20 \mu \mathrm{m}\end{array}$ & 1.42 & 1.39 & - & - \\
\hline $\begin{array}{l}\text { Cryptomonas spp. } \\
<20 \mu \mathrm{m}\end{array}$ & 2.41 & 5.32 & 2.53 & 4.60 \\
\hline $\begin{array}{l}\text { Cryptomonas spp. } \\
20-40 \mu \mathrm{m}\end{array}$ & 2.6 & 3.19 & 9.14 & 7.73 \\
\hline $\begin{array}{l}\text { Cyclotella spp. 10- } \\
15 \mu \mathrm{m}\end{array}$ & 1.51 & 1.66 & - & 1.74 \\
\hline $\begin{array}{l}\text { Cyclotella spp. 15- } \\
20 \mu \mathrm{m}\end{array}$ & - & 1.28 & - & - \\
\hline Dinobryon bavaricum & 0.78 & - & - & 1.07 \\
\hline Dinobryon divergens & - & 1.07 & - & - \\
\hline Dinobryon sp. & 0.83 & - & - & - \\
\hline Gloeotila pulchra & - & - & - & 0.74 \\
\hline
\end{tabular}




\begin{tabular}{|c|c|c|c|c|}
\hline Gonyostomum semen & 26.78 & 3.33 & 25.25 & 0.86 \\
\hline $\begin{array}{l}\text { Gymnodinium spp. } \\
>30 \mu \mathrm{m}\end{array}$ & 1.73 & - & - & - \\
\hline $\begin{array}{l}\text { Gymnodinium } \\
\text { uberrimum }\end{array}$ & - & - & 4.13 & 2.95 \\
\hline Katablepharis ovalis & 2.58 & 3.5 & - & 2.89 \\
\hline Mallomonas allorgei & - & - & - & 1.49 \\
\hline Mallomonas sp. & 1.05 & - & - & - \\
\hline Mallomonas caudata & - & 1.47 & - & 1.59 \\
\hline $\begin{array}{l}\text { Merismopedia } \\
\text { tenuissima }\end{array}$ & - & - & 3.16 & 3.9 \\
\hline $\begin{array}{l}\text { Unidentified monads } \\
<3 \mu \mathrm{m}\end{array}$ & - & - & - & 1.54 \\
\hline $\begin{array}{l}\text { Unidentified monads } \\
>10 \mu \mathrm{m}\end{array}$ & 1.69 & 1.22 & - & - \\
\hline $\begin{array}{l}\text { Unidentified monads } \\
3-5 \mu \mathrm{m}\end{array}$ & 3.33 & 2.96 & 5.84 & - \\
\hline $\begin{array}{l}\text { Unidentified monads } \\
5-7 \mu \mathrm{m}\end{array}$ & 3.34 & 4.41 & 3.78 & - \\
\hline $\begin{array}{l}\text { Unidentified monads } \\
7-10 \mu \mathrm{m}\end{array}$ & 3 & 3.06 & - & 2.79 \\
\hline $\begin{array}{l}\text { Monoraphidium } \\
\text { dybowskii }\end{array}$ & 3.21 & 1.11 & 4.63 & 3.47 \\
\hline $\begin{array}{l}\text { Monoraphidium } \\
\text { griffithii }\end{array}$ & - & - & - & 1.11 \\
\hline Monosigales spp & 0.94 & - & 2.55 & 1.24 \\
\hline Oocystis sp. & - & 1.91 & 1.45 & 1.39 \\
\hline Pediastrum privum & 1 & - & - & 0.91 \\
\hline Peridinium & 1.54 & 2.56 & 3.49 & 1.94 \\
\hline
\end{tabular}




\begin{tabular}{|c|c|c|c|c|c|}
\hline \multicolumn{6}{|l|}{ inconspicuum } \\
\hline Peridinium sp. & - & 1.29 & - & \multicolumn{2}{|l|}{-} \\
\hline Peridinium willei & - & - & 3.66 & \multicolumn{2}{|l|}{-} \\
\hline $\begin{array}{l}\text { Picoplankton } \\
\text { cyanobacteria. }\end{array}$ & - & - & - & \multicolumn{2}{|c|}{1.07} \\
\hline $\begin{array}{l}\text { Planktothrix } \\
\text { mougeotii }\end{array}$ & - & 1.76 & - & \multicolumn{2}{|l|}{-} \\
\hline Pseudopedinella sp. & 3.61 & 4.18 & 3.03 & \multicolumn{2}{|c|}{2.44} \\
\hline Rhizosolenia longiseta & - & 1.01 & 3.11 & \multicolumn{2}{|c|}{0.82} \\
\hline Rhodomonas lacustris & 2.34 & 6.03 & - & \multicolumn{2}{|c|}{5.51} \\
\hline Snowella atomus & 0.8 & - & - & \multicolumn{2}{|l|}{-} \\
\hline Spiniferomonas sp. & 1.4 & 1.02 & 1.6 & \multicolumn{2}{|c|}{1.65} \\
\hline $\begin{array}{l}\text { Stichogloea } \\
\text { doederleinii }\end{array}$ & - & - & - & \multicolumn{2}{|c|}{1.51} \\
\hline Synura sp. & - & 1.09 & - & \multicolumn{2}{|l|}{-} \\
\hline $\begin{array}{l}\text { Tabellaria flocculosa } \\
\text { var. asterionelloides }\end{array}$ & 5.08 & - & \multicolumn{3}{|l|}{2.48} \\
\hline Tetraedron caudatum & 1.59 & - & \multicolumn{2}{|l|}{-} & - \\
\hline $\begin{array}{l}\text { Tetrastrum } \\
\text { triangulare }\end{array}$ & 0.71 & - & \multicolumn{2}{|l|}{-} & - \\
\hline Trachelomonas sp. & 1.38 & - & \multicolumn{2}{|l|}{-} & - \\
\hline Uroglena sp. & 3.18 & 1.54 & \multicolumn{2}{|l|}{-} & 1.83 \\
\hline $\begin{array}{l}\text { Woronichinia } \\
\text { naegeliana }\end{array}$ & - & 2.21 & \multicolumn{2}{|l|}{-} & 0.73 \\
\hline \multicolumn{6}{|l|}{ Zooplankton } \\
\hline Asplanchna priodonta & 27.6 & 21.68 & \multicolumn{2}{|l|}{33.16} & 2.41 \\
\hline $\begin{array}{l}\text { Ceriodaphnia } \\
\text { quadrangula }\end{array}$ & 15.14 & 4.23 & \multicolumn{2}{|l|}{10.42} & - \\
\hline Conochilus unicornis & - & - & \multicolumn{2}{|l|}{1.85} & - \\
\hline
\end{tabular}




\begin{tabular}{|c|c|c|c|c|}
\hline Cyclopidae & 5.22 & 6.45 & 5.89 & 5.05 \\
\hline $\begin{array}{l}\text { Cyclopidae nauplius } \\
\text { stages }\end{array}$ & 6.74 & 6.53 & 4.58 & 5.91 \\
\hline Daphnia cristata & - & 8.61 & - & 13.87 \\
\hline Daphnia cucullata & - & - & - & 2.32 \\
\hline Daphnia galeata & 7.55 & 6.04 & - & - \\
\hline Daphnia sp. & 8.11 & 13.27 & 6.64 & 18.4 \\
\hline $\begin{array}{l}\text { Diaphanosoma } \\
\text { brachyurum }\end{array}$ & - & 3.75 & 4.18 & 6.48 \\
\hline Eubosmina coregoni & 9.99 & 13.36 & 14.81 & 20.63 \\
\hline Holopedium gibberum & 6.93 & 3.61 & - & 6.09 \\
\hline $\begin{array}{l}\text { Kellicottia } \\
\text { bostoniensis }\end{array}$ & - & - & 4.21 & - \\
\hline $\begin{array}{l}\text { Keratella cochlearis } \mathrm{f} . \\
\text { typica }\end{array}$ & - & - & - & 1.66 \\
\hline Limnosida frontosa & - & - & - & 2.44 \\
\hline Ploesoma hudsoni & - & 2.24 & - & - \\
\hline Polyarthra remata & - & - & 2.57 & 1.68 \\
\hline Polyarthra vulgaris & 3.33 & 1.97 & - & 4.36 \\
\hline Trichocerca capucina & - & - & 1.73 & - \\
\hline \multicolumn{5}{|l|}{$\begin{array}{l}\text { Littoral } \\
\text { macroinvertebrates }\end{array}$} \\
\hline $\begin{array}{l}\text { Ablabesmyia } \\
\text { longistyla }\end{array}$ & 2.13 & - & - & - \\
\hline Agrypnia obsoleta & - & - & 1.05 & - \\
\hline Argyroneta aquatica & 0.61 & - & 1.24 & 1.3 \\
\hline Asellus aquaticus & 10.67 & 10.47 & 12.89 & 13.47 \\
\hline Athripsodes sp. & - & 0.63 & - & - \\
\hline Bivalvia (total) & 3.42 & 2.93 & 3.08 & 2.98 \\
\hline
\end{tabular}




\begin{tabular}{|c|c|c|c|c|}
\hline Caenis horaria & 5.59 & 4.66 & - & 4.08 \\
\hline Caenis luctuosa & 13.02 & 6.79 & - & 7.51 \\
\hline Centroptilum luteolum & 1.53 & 2.84 & - & 1.1 \\
\hline Ceratopogonidae & 3.32 & 2.96 & 2.74 & 2.42 \\
\hline $\begin{array}{l}\text { Heterotanytarsus } \\
\text { apicalis }\end{array}$ & 0.84 & - & - & - \\
\hline Holocentropus sp. & - & - & 0.98 & - \\
\hline Hydracarina & 2.29 & 2.19 & 2.83 & 2.58 \\
\hline Hydroptila sp. & - & 0.84 & - & - \\
\hline Kageronia fuscogrisea & 4.15 & 3.89 & 2.83 & 1.63 \\
\hline $\begin{array}{l}\text { Lauterborniella } \\
\text { agrayloides }\end{array}$ & - & - & 2.28 & 1.8 \\
\hline Lepidostoma hirtum & - & 0.68 & - & 1.08 \\
\hline $\begin{array}{l}\text { Leptophlebia } \\
\text { marginata }\end{array}$ & 3.32 & 4.9 & 1.35 & 2.24 \\
\hline $\begin{array}{l}\text { Leptophlebia } \\
\text { vespertina }\end{array}$ & 5.63 & 15.91 & 17.96 & 9.57 \\
\hline Libellulidae & - & - & 0.87 & - \\
\hline Limnephilus sp. & - & - & 1.58 & - \\
\hline Marstoniopsis scholtzi & - & - & - & 0.85 \\
\hline Micronecta sp. & - & - & - & 1.96 \\
\hline Microtendipes sp. & 1.03 & - & - & - \\
\hline Molannodes tinctus & - & - & 1.02 & - \\
\hline Molanna angustata & - & - & - & 0.75 \\
\hline Mystacides azurea & 1.56 & 0.82 & - & 1.87 \\
\hline $\begin{array}{l}\text { Mystacides } \\
\text { longicornis/nigra }\end{array}$ & 1.6 & 1.28 & 1.37 & 2.02 \\
\hline $\begin{array}{l}\text { Nebrioporus } \\
\text { depressus }\end{array}$ & 0.63 & - & - & - \\
\hline
\end{tabular}




\begin{tabular}{|c|c|c|c|c|}
\hline Nemoura avicularis & - & 1.63 & - & 2.12 \\
\hline Oecetis testacea & 2.26 & 0.99 & - & - \\
\hline Oulimnius sp. & 0.8 & - & - & - \\
\hline $\begin{array}{l}\text { Oulimnius } \\
\text { troglodytes- } \\
\text { tuberculatus }\end{array}$ & 1.75 & 1.18 & - & 1.18 \\
\hline Oxyethira sp. & - & - & 1.44 & 2.32 \\
\hline Pagastiella orophila & 2.3 & 3.98 & - & 1.14 \\
\hline Paramerina sp. & - & - & 2.89 & 1.12 \\
\hline Phaenopsectra sp. & - & 2.45 & 1.12 & - \\
\hline Pisidium sp. & 3.42 & 1.82 & 3.08 & 2.92 \\
\hline $\begin{array}{l}\text { Platycnemis penn.- } \\
\text { Pyrrhosoma nymph. }\end{array}$ & 2.41 & - & 1.82 & \\
\hline $\begin{array}{l}\text { Polycentropus } \\
\text { flavomaculatus }\end{array}$ & 1 & - & - & - \\
\hline $\begin{array}{l}\text { Polypedilum } \\
\text { breviantennatum } \\
\text { group }\end{array}$ & 1.8 & - & 0.99 & - \\
\hline Procladius sp. & 3.8 & 3.43 & 4.16 & 1.25 \\
\hline Psectrocladius sp. & 2.01 & 0.92 & 8.45 & 3.47 \\
\hline $\begin{array}{l}\text { Pseudochironomus } \\
\text { prasinatus }\end{array}$ & - & 1.17 & 2 & 1.77 \\
\hline Sialis lutaria & 0.93 & 0.78 & 2.28 & 0.78 \\
\hline Stenochironomus sp. & - & - & 1.44 & - \\
\hline Tanytarsus sp. & 5.52 & 0.9 & 3.7 & 4.26 \\
\hline $\begin{array}{l}\text { Thienemannimyia } \\
\text { group }\end{array}$ & 1.66 & 0.63 & 1.61 & 0.74 \\
\hline Tinodes waeneri & 0.85 & - & - & 1.28 \\
\hline Turbellaria & - & - & - & 1.41 \\
\hline
\end{tabular}




\begin{tabular}{|c|c|c|c|c|}
\hline Zygoptera & 0.72 & - & - & 2.41 \\
\hline \multicolumn{5}{|l|}{$\begin{array}{l}\text { Sublittoral } \\
\text { macroinvertebrates }\end{array}$} \\
\hline Anisoptera & 5.43 & 12.61 & - & - \\
\hline Athripsodes sp. & 5.49 & 10.65 & - & 8.05 \\
\hline Ceratopogonidae & 18.31 & 5.83 & 14.02 & 8.55 \\
\hline Chaoborus flavicans & 13.66 & 22.58 & 30.56 & 20.84 \\
\hline Coenagrion sp. & 3.53 & - & - & - \\
\hline Ephemera sp. & 4.91 & - & - & 5.3 \\
\hline Molanna albicans & 2.99 & - & - & - \\
\hline Physa fontinalis & 5.49 & 10.65 & - & 8.05 \\
\hline Sialis fuliginosa & - & - & 6.86 & 8.8 \\
\hline Valvata piscinalis & 33.09 & 33.22 & 39.45 & 31.7 \\
\hline \multicolumn{5}{|l|}{$\begin{array}{l}\text { Profundal } \\
\text { macroinvertebrates }\end{array}$} \\
\hline Bivalvia (total) & - & 10.24 & - & - \\
\hline Chaoborus flavicans & 80.52 & 30.45 & 78.6 & 61.76 \\
\hline Chironomidae (total) & 14.61 & 28.55 & 20.9 & 14.72 \\
\hline Oligochaeta (total) & - & 14.49 & - & 23.52 \\
\hline Pisidium sp. & - & 10.24 & - & - \\
\hline \multicolumn{5}{|l|}{ Fish } \\
\hline Perca fluviatilis & 36.61 & 38.13 & 44.77 & 30.3 \\
\hline Leuciscus rutilus & 31.4 & 26.54 & 29.53 & 21.03 \\
\hline Salvelinus alpinus & 22.22 & - & - & - \\
\hline Esox lucius & - & 11.87 & 14.94 & 15.22 \\
\hline Abramis brama & - & 9.41 & 6.84 & 11.68 \\
\hline Tinca tinca & - & - & - & 6.84 \\
\hline Coregonus lavaretus & - & 7 & - & 5.63 \\
\hline
\end{tabular}




\section{Appendix 2}

Correlations between organic carbon, indicative of light conditions, and Gonyostomum semen abundance in the lakes. For this analysis we calculated specific absorption ratio at 420nm (SAR420) by dividing the absorbance measured at $420 \mathrm{~cm}$ in a $5 \mathrm{~cm}$ cuvette with the measured TOC concentrations.

The analysis of SAR420 as a function of $\mathrm{pH}$ revealed specific patterns (Figure A2.1). Regarding the limed lakes, naturally acidic limed lakes had higher SAR420 and thus higher absorbance (darker light conditions due to lighter carbon) than the acidified, limed lakes (upper panel; Figure A2.1). Comparing circumneutral and acidified unlimed lakes shows generally higher absorbance and thus darker light conditions in the latter lake group, correlating with lower $\mathrm{pH}$ values (middle panel; Figure A2.1). Comparing all lake types with each other (lower panel; Figure A2.1) shows that naturally acidic limed lakes have higher SAR420 values, indicating darker light conditions. Taken together these results are in accordance with earlier findings (Erlandsson et al. 2008), and related to the processing of organic carbon in lakes and the speciation of iron (Köhler et al. 2013).

The regional distribution and abundance patterns across lakes in Sweden of Gonyostomum semen, a mixotrophic species with both autotrophic and heterotrophic feeding modes, has been shown to correlate with increasing organic carbon concentration associated with recovery from acidification from lower to higher acidic $\mathrm{pH}$ condition and the associated increase of darker light condition in the lakes (Angeler et al. 2012). Liming as a management strategy seems to increase organic carbon of naturally brown acidic lakes to higher concentrations, favouring Gonyostomum. Our analysis shows how natural dynamics and management can be associated with linked geochemical and biological patterns. 
Figure A2.1

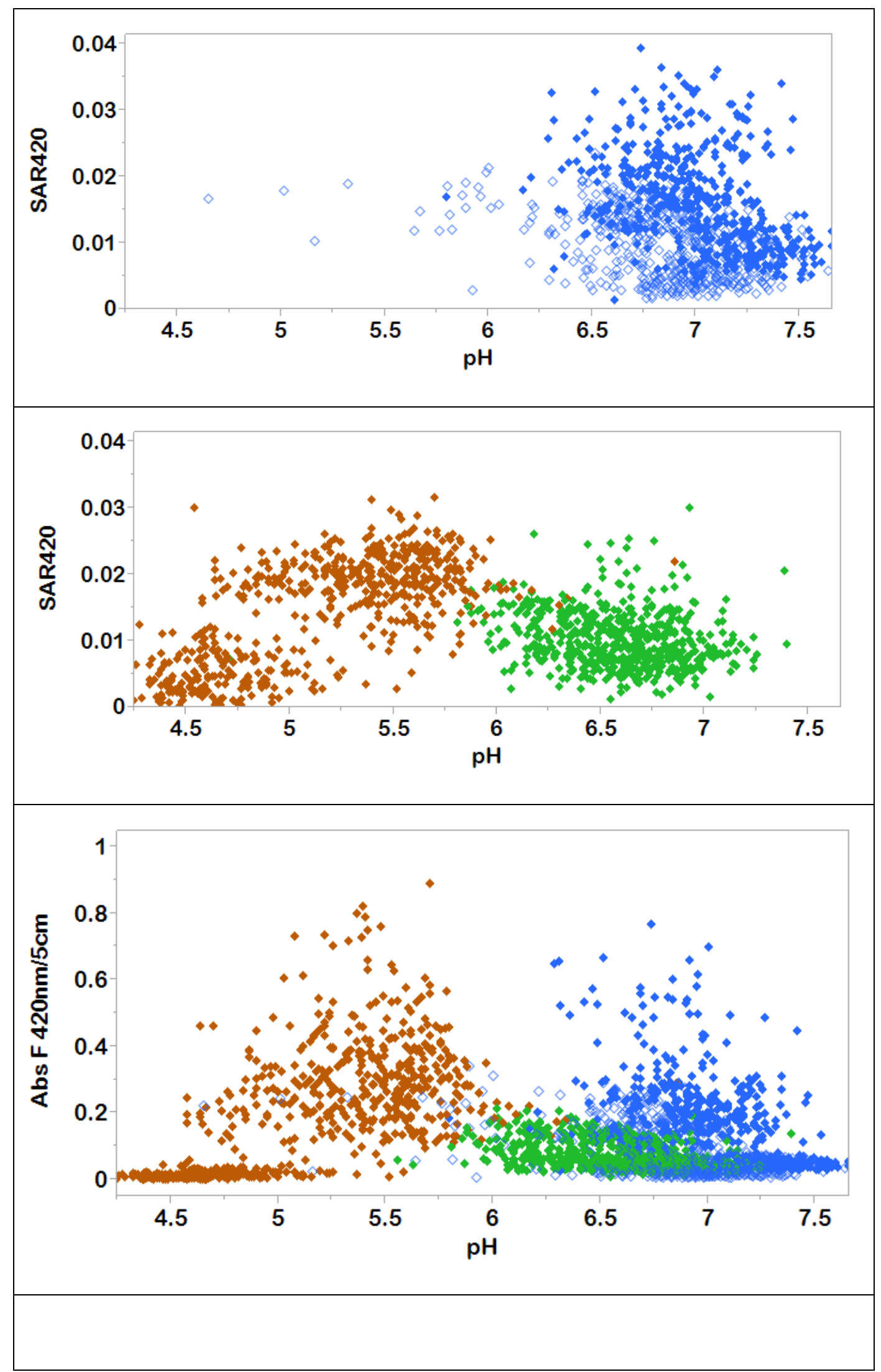


Figure A2.1: Specific absorption ratio SAR420 as a function of $\mathrm{pH}$. Upper panel: for the acidified limed (full blue diamonds; naturally acid limed lakes (empty blue diamonds). Middle panel: acidified unlimed (brown symbols) and circumneutral lakes (green symbols). Lower panel: all lake types included in this study (symbols are as in upper and middle panel).

\section{References}

Angeler, D.G., C. R. Allen, and R. K. Johnson, R.K. 2012. Insight on invasions and resilience derived from spatiotemporal discontinuities of biomass at local and regional scales. Ecology and Society 17(2): 32. [online] URL: http://www.ecologyandsociety.org/vol17/iss2/art32/

Erlandsson, M., I. Buffam, J. Fölster, H. Laudon, J. Temnerud, G. A. Weyhenmeyer, and K. Bishop. 2008. Thirty-five years of synchrony in the organic matter concentrations of Swedish rivers explained by variation in flow and sulfate. Global Change Biology 14: $1191-1198$.

Köhler, S. J., D. Kothawala, M. N. Futter, O. Liungman, and L. Tranvik. 2013. In-lake processes offset increased terrestrial inputs of dissolved organic carbon and color to lakes. PloS one 8(8): e70598. 